Planning Theory \& Practice

\title{
Participation, scenarios and pathways in long-term planning for climate change adaptation
}

\section{Inês Campos, André Vizinho, Carlos Coelho, Fátima Alves, Mónica Truninger, Carla Pereira, Filipe Duarte Santos \& Gil Penha Lopes}

To cite this article: Inês Campos, André Vizinho, Carlos Coelho, Fátima Alves, Mónica Truninger, Carla Pereira, Filipe Duarte Santos \& Gil Penha Lopes (2016): Participation, scenarios and pathways in long-term planning for climate change adaptation, Planning Theory \& Practice, DOI: 10.1080/14649357.2016.1215511

To link to this article: $\mathrm{http}: / / d x . d o i . o r g / 10.1080 / 14649357.2016 .1215511$

曲 Published online: 08 Sep 2016.

Submit your article to this journal $\asymp$

Џll Article views: 100

Q View related articles $\asymp$

View Crossmark data \lceil 


\title{
Participation, scenarios and pathways in long-term planning for climate change adaptation
}

\author{
Inês Campos ${ }^{a}$, André Vizinho ${ }^{a}$, Carlos Coelhob ${ }^{b}$,átima Alves ${ }^{c}$, Mónica Truningerd ${ }^{\text {, Carla Pereira }}{ }^{\mathrm{b}}$, \\ Filipe Duarte Santos ${ }^{\mathrm{a}}$ and Gil Penha Lopes ${ }^{\mathrm{a}}$
}

aCentre for Ecology, Evolution and Environmental Changes (CE3C) Faculty of Sciences, Universidade de Lisboa, Lisbon, Portugal; ${ }^{b}$ Risco and Department of Civil Engineering, Universidade de Aveiro, University Campus of Santiago, Aveiro, Portugal; ' ${ }^{C}$ Centre for Environmental and Marine Studies (CESAM), Department of Environment and Planning, Universidade de Aveiro, University Campus of Santiago, Aveiro, Portugal; 'Instituto de Ciências Sociais (ICS), Universidade de Lisboa, Lisbon, Portugal

\begin{abstract}
This article describes a climate change adaptation planning process triggered by a group of researchers and stakeholders in a context where no collective responses or long-term plans for protecting a vulnerable coastal system had been initiated, despite local perceptions of vulnerability and risk. The case study shows the application of two methods: scenario workshops and adaptation pathways in the context of a participatory action research methodological design. Participatory action research and qualitative scenario methods are highlighted as accelerators of climate change adaptation processes by calling to action, facilitating and connecting diverse social groups with a stake in a long-term plan towards a more adapted society. The experience leads to the conclusion that planning climate change adaptation has to go far beyond the technical dimension and take into account those affected (in the present and the future) by decisions made. $A$ holistic approach to climate change adaptation planning will depend on the interrelations of managerial and top-down approaches with localized initiatives driven through an inclusive and collective action research process.
\end{abstract}

ARTICLE HISTORY

Received 27 May 2015

Accepted 18 July 2016

\section{KEYWORDS}

Climate change adaptation; long-term; scenario workshop; adaptation pathways; participation

\section{Introduction}

There is a significant role for participatory action research and scenario method approaches in planning for climate change. Adaptation to climate change impacts should reduce vulnerability, or the degree to which a system is susceptible to the adverse effects of climate change, while taking advantage of potential opportunities (Adger, 2006). To some degree inevitable in many parts of the world, climate change adaptation may be an opportunity to promote development pathways towards more adapted and resilient societies today and in the future (Westley et al., 2011; Pelling, O'Brien, \& Matyas, 2014). In this context adaptation is conceptualized as "an element of pathways of interacting global changes and societal responses" (Wise et al., 2014, p. 332). Well beyond mere technical solutions, adaptation calls for multidisciplinary approaches and for the active involvement of a diversity of actors in decision-making processes. Wise and colleagues suggest a paradigmatic shift is required that encompasses key dimensions of climate change adaptation (still overlooked in research and practice), including cultural and 
political dynamics (Wise et al., 2014). Such a shift should entail taking into account the specificities of diverse geographic and social contexts, where there is a need for planning experiences that integrate how local values and worldviews influence policies and actions (Adger et al., 2013). Planning climate change policies should make use of inclusive participatory processes (Amaru \& Chhetri, 2013). A transdisciplinary ontology (Hadorn, Bradley, \& Pohl, 2006) is better equipped to respond to complex societal concerns by working across scientific fields and disciplines and involving multiple knowledge domains including local and traditional knowledge (Folke, Hahn, Olsson, \& Norberg, 2005). Moreover, framing - or the interpretative storylines that guide action - has been considered important for public engagement in climate change policy (Nisbet, 2009; Porter, Demeritt, \& Dessai, 2015).

This article describes a climate change adaptation planning process triggered by a group of researchers and stakeholders in a context where no collective responses and long-term plans for protecting a coastal system had been initiated, despite local perceptions of vulnerability and risk. Participatory action research and qualitative scenario methods are highlighted as accelerators of climate change adaptation by calling to action, facilitating and connecting diverse social groups with a stake in longterm solutions for a more adapted society. Although the methodological approach was designed to respond to specific challenges, its application can be replicable in other contexts.

\section{Challenges for climate change adaptation and research objectives}

Climate change adaptation research has underlined a number of challenges for local action. Interactions between different scales and levels of governance are complex (Juhola \& Westerhoff, 2011; Tompkins et al., 2010) and can benefit from participatory approaches that allow for an effective mediation, translation and negotiation across scales (Agarwal, Perrin, Chatre, Benson, \& Kononen, 2012; Cash et al., 2006). The long time frame of climate change adaptation processes raises a number of issues. Long-term planning can be difficult for local administrations due to political and electoral short-term dynamics (Berrang-Ford, Ford, \& Paterson, 2011). It poses strains in funding, particularly expensive engineering interventions (Ford, Berrang-Ford, \& Paterson, 2011). These problems increase with the challenge in identifying what constitutes adaptation, and in keeping track of progress on adaptation processes (Ford, Berrang-Ford, Lesnikowski, Barrera, \& Heymann, 2013). Adaptation options may transform the dynamics of social-ecological systems when they require engineering interventions with potential secondary effects (Kates, Travis, \& Wilbanks, 2012). While the effectiveness of mitigation (i.e. reducing global greenhouse gas emissions) has a high degree of certainty, the effectiveness of adaptation does not, and monitoring is challenging. Planning climate change adaptation can be constrained by uncertainties regarding what an adaptation measure is (Ford et al., 2013), which may lead to adaptation processes being framed as something else in the political context, for instance, as "resilience to extreme weather events" (Porter et al., 2015).

Another challenge refers to equity considerations, namely who are the losers and winners of decisions taken, or how adaptive capacity is distributed (O'Riordan, Gomes, \& Schmidt, 2014). Long-term plans should involve a diversity of social actors in co-developing and envisioning futures, yet this is problematic when participation is not common in policy-making processes (Carvalho, Schmidt, Santos, \& Delicado, 2014). It can also be difficult to mediate the different perceptions on climate change. For instance, while scientists may attempt to develop integrated and holistic approaches (Wise et al., 2014), local actors may prefer a more action oriented and simplistic focus (Alves et al., 2014). Adding to equity considerations, climate change adaptation faces a high level of complexity and uncertainty (regarding climate impacts and the effectiveness of adaptation policies). 
Portugal offers a good case to investigate how some of these challenges can be addressed. National and local climate change adaptation policies are still emerging (Carvalho et al., 2014). The National Adaptation Strategy (PNAS, 2013) was launched in 2010 as a non-binding programme, but did not translate into official guidelines for action planning (O'Riordan et al., 2014). At the local level, only three municipalities (from a total of 308) have a climate strategy. Accordingly, Portugal appears in European reports as a very vulnerable country with highly adverse climate integrated impacts and low levels of capacity to adapt (ESPON, 2013).

Coastal zones in Portugal are particularly vulnerable to rising sea levels and storm surges (Santos \& Miranda, 2006). The case study presented in this article refers to the coast of Ílhavo and Vagos. Previous studies in the area have highlighted a high perception of risk among local social actors (Schmidt, Gomes, Guerreiro, \& O'Riordan, 2014; O'Riordan et al., 2014). Two vulnerability assessments concluded that an inter-municipal long-term plan for the future would be needed (Alves, Sousa, Almodovar, \& Phillips, 2013; Schmidt et al., 2014). Yet, despite known vulnerabilities, the coastal area does not have a plan for climate change adaptation. Administratively, the region is characterized by a high level of complexity due to multiple institutional bodies responsible for coastal management (Alves, Silva, Pereira, \& Sousa, 2011). In Portugal, mainland coastal zones are managed by five shoreline plans with a short-term strategy (a horizon of 10 years) (Alves et al., 2011), called the coastal zone management programmes. The programme for the Ovar-Marinha Grande stretch comprises the case study area but does not include a specific strategy for dealing with climate change. Regarding public participation, O'Riordan and colleagues noted a "discouragement and distrust on the part of social actors to participate" in planning processes, and that these are not "recognized as partners by the political powers." (O'Riordan et al., 2014, p. 14).

To meet these challenges, planning climate change adaptation requires well-developed methodologies and tools, including participatory and capacity building approaches that provide effective means of supporting decision-making and collective action (Dannevig, Rauken, \& Hovelsrud, 2012; Juhola \& Westerhoff, 2011). These approaches should offer a wide and inclusive role for stakeholders who acquire the necessary knowledge and are empowered to lead together the planning process. Particularly, participatory action research (McNiff, 2013) can support such social learning experiences, through interactive and group dynamics (Armitage, Marschke, \& Plummer, 2008). Additionally, participatory scenario approaches have the ability to promote thinking "out of the box" and create a wider involvement of relevant stakeholders (Sondeijker, 2009).

By analysing a case study in Portugal, the article aims at understanding the role of participatory action research and scenario approaches in addressing challenges posed by climate change adaptation. These are the long time frame of adaptation processes, a high level of uncertainty and complexity regarding options for protecting the coastal system, and the inter-institutional collaborations required to respond to a problem that needs to account for different stakes and interests.

By proposing a methodological design based on specific principles (inclusiveness, promoting a long-term perspective, and accounting for uncertainty and complexity), the case study aims at contributing to a fuller theory of climate change adaptation that integrates the scientific dimension of climate change responses within social learning processes. Specifically, the article hypothesizes that participatory action research and scenario methods lead to an inclusive and shared vision towards the long-term that accelerates climate change adaptation at the local level by mediating between diverse stakeholder groups and by stimulating action.

In what follows, the case study area is characterized, explaining in detail the methodological approach and providing an overview of the results. The discussion addresses key insights and lessons 
learned from this case study. Finally, the conclusion offers a synthesis of the main findings and its contributions for climate change planning and future research.

\section{The coast of Îlhavo and Vagos}

The area studied is the coastal stretch of Ílhavo and Vagos, comprising the area between Barra Beach (Ílhavo) and Areão Beach (Vagos) (see Figure 1). This coast has been recognized as one of the most vulnerable low-lying coasts in Europe, when it comes to storm surges and flood risks (Alves et al., 2011; Santos \& Miranda, 2006). From the geomorphological point of view the study area is a dune barrier along a stretch of nearly $20 \mathrm{~km}$ on the west coast of Portugal, comprising the municipalities of ílhavo and Vagos. It extends from the mouth of the Ria de Aveiro lagoon along a low-lying sand spit between the sea and the lagoon. The territory is characterized by the presence of three urban settlements (Barra, Costa Nova and Vagueira) occupied by permanent and secondary homes, and also fishing communities. Land cover between these settlements is mostly composed of wetlands, sandy beaches and dunes, agricultural areas, roads, as well as touristic and harbour infrastructures.

The coast is highly exposed to a very energetic wave climate (Coelho, Silva, Veloso-Gomes, \& TaveiraPinto, 2009), currently suffering from strong erosion, mainly due to a deficit of sediments associated with a reduction in river sediments supply (Pereira \& Coelho, 2013). Recent studies point to a sea level rise of up to a metre in 2100 (Dias \& Alves, 2013). Indirect climate impacts include aggravated coastal erosion and loss of sandy beach areas and dune systems, recurrent ocean and fluvial floods, potential loss of revenues in tourism and nautical sports, and damage to coastal defence structures and urban infrastructures (Alves et al., 2014; Coelho et al., 2009). The risk of a new connection between the sea and the lagoon, leading to a new inlet in the coastal lagoon, would have severe socio-economic and environmental consequences for coastal settlements (Coelho et al., 2009). Yet, despite these well-known risks, no adaptation plan was being developed. The following sections describe how participatory action research and scenario methods accelerated the planning process.

\section{Methodology}

To account for the challenges of climate change adaptation the research leading to this article was implemented through an action research process (Altrichter, Kemmis, McTaggart, \& Zuber-Skerritt, 2002; McNiff,

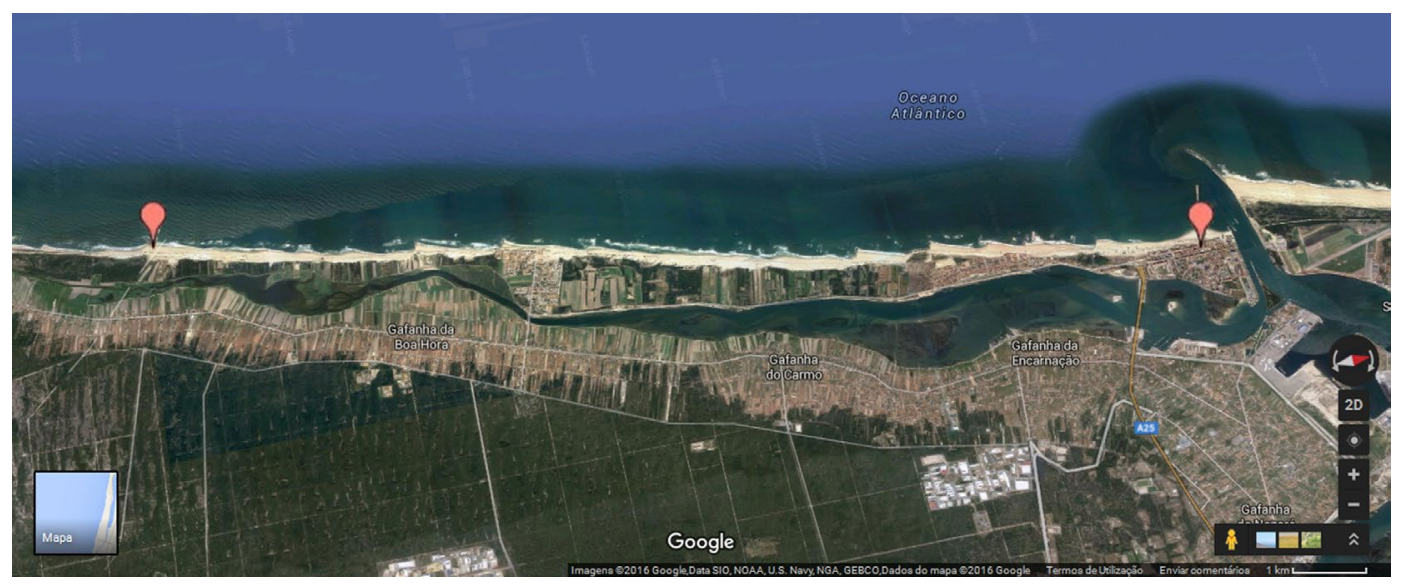

Figure 1. Images@2016 Google, Data SIO, NOAA, U.S. Navy, NGA, GEBCO, Dados do mapa@2016 Google. 
2013; Wittmayer \& Schäpke, 2014), which differs from conventional research due to its cyclical nature and its progression block by block (Altrichter et al., 2002; Avgitidou, 2009). The research included the active participation of local stakeholders. The creation of an action group (i.e. the core group of individuals involved, see McNiff, 2013) was based on the principle that those with a stake in the issue would be active managers of the adaptation plan. The case study was also a transdisciplinary research experience (Hadorn et al., 2006), involving a number of scientific disciplines and knowledge domains. The criterion for selecting participants was to identify the beneficiaries of climate change adaptation in the region, as well as important actors for implementing policies and measures (Larsen \& Gunnarsson-Östling, 2009; Wood \& Stocker, 2009). The group of participants included representatives of local administrations (e.g. municipality mayors, policymakers and spatial planners, the Aveiro Harbour Administration), regional and national administrative bodies (e.g. regional association of municipalities, the National Environmental Agency), environmental associations, the Aveiro University (close to the case study area), associations of local business owners, professional associations of farmers and fisherman, surfers and resident associations.

The action research cycle integrated four components: diagnosis of the problem, planning the research activities, implementing the research activities with the participants, and evaluating the process experienced (Jäger, Bohunovsky, \& Binder, 2008; McNiff, 2013). Different methods and tools were used at each stage and are described below.

\section{Diagnosis}

The diagnosis stage started with a literature review of previous studies, complemented by informal meetings with representatives of the municipalities and local communities involved. The conversations held during these meetings highlighted the need to provide a strong knowledge base on climate change, and two seminars were organized in the nearby Aveiro city, offering presentations from researchers and invited speakers on climate change impacts and adaptation options for coastal regions. An average of 70 people attended the seminars, asked questions and debated adaptation options with the researchers.

During this period, climate change scenarios for the region were collected from earlier research projects (Dias \& Alves, 2013). Previous studies relied on climatic scenarios from the fourth Intergovernmental Panel on Climate Change (IPCC) (Parry, Canziani, Palutikof, Van der Linden, \& Hanson, 2007; Solomon et al., 2007). These studies modelled several scenarios, but only two were used in the case study interactions, which were called scenario C4 (strong climate change) and scenario C3 (intermediate climate change).

The two scenarios were prepared to be presented to stakeholders in the form of geographical information system (GIS) maps. One map showed projections of changes on the shoreline due to erosion, considering sediment dynamics and climate change impacts (i.e. sea level rise, wave height) (Pereira \& Coelho, 2013; Fortunato, Rodrigues, Dias, Lopes, \& Oliveira, 2013; Lopes et al., 2011). Another map showed the risk of overtopping and floods until 2100 (Schmidt et al., 2013a; Schmidt, Prista, Saraiva, O'Riordan, \& Gomes, 2013b; Schmidt et al., 2014). Flood risk areas were clearly identified in the maps, with variations over a period of 100 years. Tipping-points, corresponding to rises in sea level and coastal erosion, were identified on the timeline for 2040, 2070 and 2100.

\section{Planning and implementation}

The planning and implementation stages of the methodology progressed through the use of the scenario workshop and adaptation pathways methods (the integration of the two methods is henceforth 
referred to as SWAP). The application of these methods provided a way of addressing key challenges for climate change adaptation planning (e.g. a long time frame, uncertainty and complexity), but also began a planning process in a context where there has been neither a culture of participation, nor an active inter-institutional collaboration.

Opting for applying the scenario workshop method (Andersen \& Jaeger, 1999; Schmidt-Thomé \& Klein, 2013) was a way to encourage thinking "out of the box" and lead participants to envision possible future system states for their territory. A shared vision should allow the co-construction of an interpretative storyline which would be motivating for building up local adaptive capacity (Nisbet, 2009). Planning the scenario workshops led to a set of meetings with participants to organize and publicize the event. A representative group of 30 people, identified by their respective communities and stakeholder groups, was invited to participate.

During the first workshop day participants discussed three alternative storylines based on future scenarios for the coastal region. The storylines were based on climate change scenarios and risk assessment maps and were purposely extreme and normative (Larsen \& Gunnarsson-Östling, 2009) to promote a critical discussion (Schmidt-Thomé \& Klein, 2013). The storylines were read by the workshop facilitator as fictional narratives, and provided three alternative visions of what the future could be according to different courses of action. Table 1 provides a synthesis of these alternative storylines.

Common goals were identified through the discussions and a fourth alternative emerged, which included the proposal for adaptation actions for the following 75 years. The facilitators encouraged participants to work together (Avgitidou, 2009). The GIS maps were displayed on the tables. Participants were supplied with office materials (pencils, coloured pens, plasticine, post-its, pins, and scissors) and asked to mark their preferred options for coastal protection on the maps.

The second workshop day started with the presentation of potential adaptation measures resulting from the first day's common vision, including notes on possible costs, benefits, efficacy, uncertainty and secondary effects of a range of technical options. The adaptation pathways and tipping-points tool (Haasnoot, Kwakkel, Walker, \& ter Maat, 2013) was included in the methodology to help determine policies and alternative trajectories under different scenarios for the future, and under conditions of substantial uncertainty (Walker, Haasnoot, \& Kwakkel, 2013). The pathways acknowledge the lack of equilibrium in natural system states, and the difficulty in identifying an ideal strategy for the long term. They presuppose a set of policies dependent on variable conditions, signposted by future thresholds or tipping-points (Kwadijk et al., 2010). Tipping-points refer to moments in time when an adaptation policy ceases to be effective and a new policy is needed to respond to the new conditions (Haasnoot et al., 2013). The resulting strategies, policies or measures shape the alternative trajectories.

The pathways were developed as a computationally based scenario tool (Haasnoot et al., 2013), which made it challenging to use in a participatory context. To overcome this challenge and maintain the integrity of the tool, the pathways were formulated in four stages. First, between the two workshop days researchers produced a set of pathways for the region using Visio software (Visio, 2010) similarly

Table 1. Synthesis of three alternative storylines presented to participants.

\begin{tabular}{ll}
\hline Scenario & Do nothing and maintain existing coastal defence structures, resulting in serious flooding events and damage to \\
A & Puman settlements and infrastructures with great economic losses \\
B & $\begin{array}{c}\text { protect everything, resulting in an artificial coast, with massive investments in a series of constructions (dykes and } \\
\text { breakwaters), which radically change the natural landscape, as well as economic and social life in the region }\end{array}$ \\
R & $\begin{array}{l}\text { Relocate, allowing the sea to advance and coastal erosion to continue at will, some local settlements being aban- } \\
\text { doned, and the region gaining a pristine ecological value }\end{array}$ \\
\hline
\end{tabular}


employed by Haasnoot and colleagues (2013). This set of pathways was made for five sub-areas of the coastal stretch, due to geographic specificities and to facilitate the discussion among participants, who would later work with the areas they were better acquainted with. Second, the pathways were printed and left on the room's working tables. Participants organized themselves into discussion groups, and were given the task of choosing or creating new pathways for each subarea. The new pathways were sketched by the groups on top of the original prints (see an example in Figure 2). Third, an appointed spokesperson from each group presented the sketched pathways, while the facilitator designed the pathways using the software. The computer versions of the sketched pathways were seen by the whole group via the room's projector. Fourth, following the workshops, the pathways were aggregated into a single pathway for the whole coast, representing a synthesis of the resulting action plan of the scenario workshop. A report was then sent to all participants, which included the final pathways, with a representation of potential coastal adaptation policies and measures.

\section{Evaluation}

The evaluation component started at the end of the second workshop day, when participants were asked who they thought should be accountable for implementing and financing the action plan, and were invited to enumerate issues that could enable or constraint implementation. Participants were also asked what they felt the following research steps should be, and the role they could play in that process. The evaluation was complemented by feedback interviews and by the researchers' notes of conversations with participants. A number of participants (10 out of 25) were interviewed and offered insights concerning what they had learned throughout the engagement processes. The interviews followed a semi-structured guide based on three themes: promoting long-term planning, the strengths and weaknesses of the participatory process, and strategies needed to support implementation.

\section{Results}

The initial research stage (i.e. diagnosis) lasted roughly six months and conveyed a number of key insights for what followed. Despite local awareness of vulnerabilities and risks, the situation had reached a standstill regarding planning effective responses to the perceived and potential impacts of erosion and of climate change on the coastal system. The making of a long-term action plan would have to involve at least two municipalities affected by the problem (i.e. Ílhavo and Vagos). While it was easier than anticipated to engage local stakeholders in a discussion on climate change and coastal protection, participants manifested a number of grievances. There was a particular division between policymakers (e.g. municipal mayors), sectoral administrators (e.g. the Aveiro Harbour) and civil society groups (i.e. professional, resident and environmental associations). The latter somewhat blamed political actors for the negative consequences of past decisions on the coastal system (i.e. the dams built in river streams to the north had reduced the natural flow of sediments to the coast, leading to increased erosion). Despite these tensions local stakeholders for the most part claimed they had not been appropriately involved and were highly inclined to engage in a conversation. The scenario workshop offered the opportunity to initiate this dialogue.

\section{The scenario workshop}

The scenario workshop started with the presentation of the three alternative storylines to initiate the discussion on climate change. About a third of the participants expressed doubts regarding current climate projections. As the day progressed participants came to accept that, despite climate change, a plan 
Troço 3 : Entre a Costa Nova e a Vagueira

Objectivo: Impedir a Rotura do Cordāo Dunar e

impedir a ligaçāo do Mar à Ria

\section{CAMINHOS DE ADAPTAÇÃO}

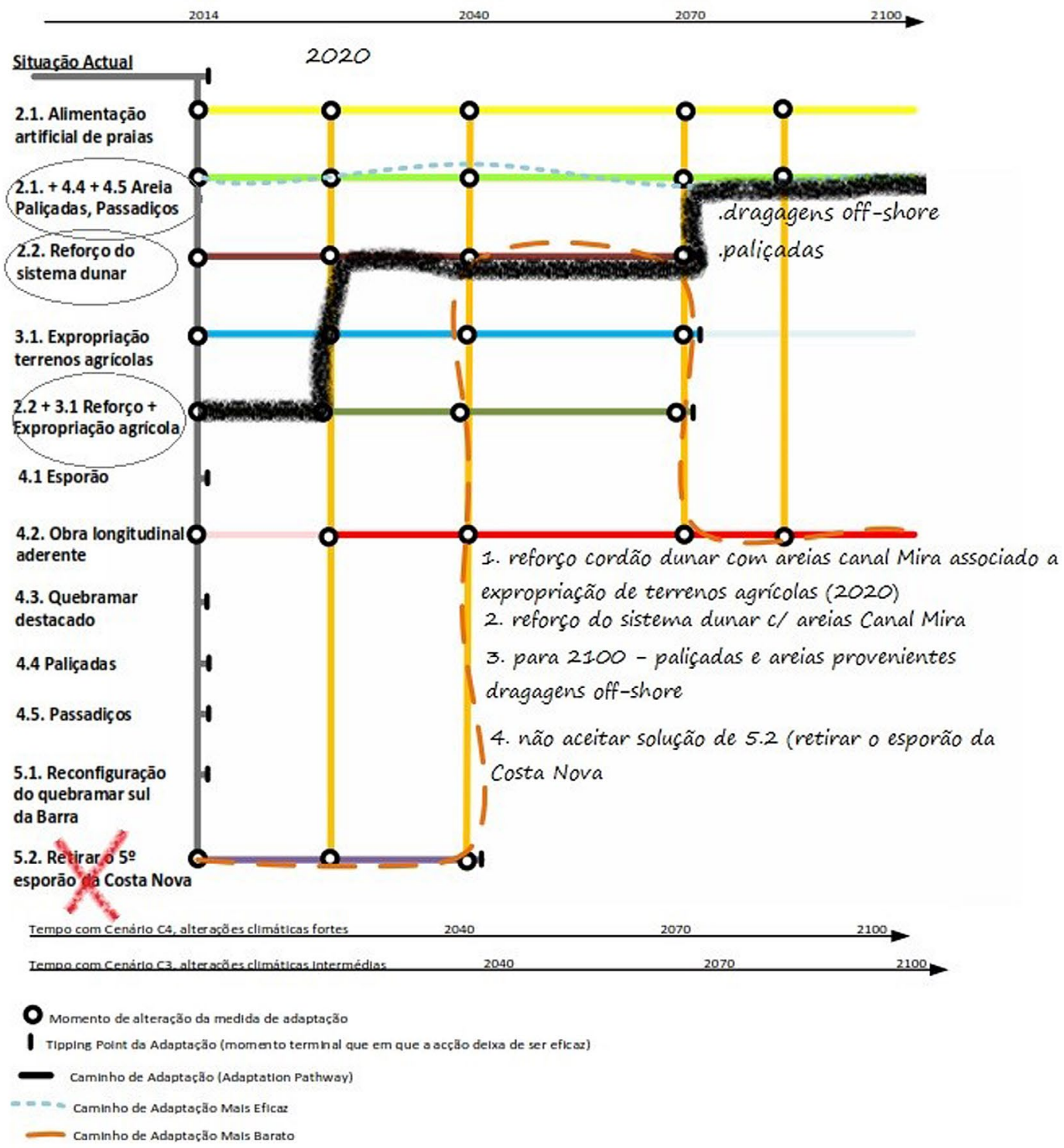

Figure 2. Adaptation pathways for sub-area 3 edited by participants.

Notes: 1. Reinforce the dune system with sand from the Mira canal - related to the expropriation of farming lands (2020), 2. Reinforce the dune system with sand from the Mira canal, 3. For 2100 - sand taken from off-shore sites, 4. Do not accept solution 5.2 (to retrieve the Costa Nova groyne)

would be needed to resolve the coastal erosion problem. Dealing with coastal erosion emerged as an important framework for motivating action. Yet most participants manifested a short-term focus -“we 
need to act now"; "we need sand on the beach". Experts claimed a long-term strategy would prevent dealing with emergency situations, which could result in losses of lives and goods; "What cannot happen is to act on emergency situations, it's extremely expensive and dangerous" cautioned an engineer. These arguments were supported by the storylines presented and the GIS maps displayed on the tables. Towards the end of the day the need for long-term planning was generally accepted.

\section{Critique of storylines}

Participants, particularly policymakers, manifested their opposition to the idea of relocating (which was part of storyline $C$, see Table 1). Some residents (who had the most to lose) and national level administrators found relocation could be needed in the long-term, suggesting a progressive relocation of coastal zone constructions in urban settlements. Protecting everything (i.e. storyline B) was controversial due to high financial investments needed and to the dramatic changes that dykes and breakwaters could have on the local ecosystem. As someone noted, "we do not want a coast of steel". Some participants also mentioned the importance of revising legislation for building on the shoreline, others claimed legislation existed, but was not being properly applied. This issue was not discussed further in the following workshop sessions.

\section{Technical complexity}

In considering the need for protection measures several solutions were discussed (see Table 2). Except for the engineers, there was an overly simplistic assumption regarding the technicalities of coastal protection. Most participants were not aware of the multiplicity of options available. The engineers in the room explained that every option implied a significant number of alternative techniques. For instance, it was explained that placing sand on the sea's longitudinal drift current was as efficient as placing sand directly on the beach, although the two options had different costs. At the beginning of the discussions a policymaker argued for a "submerged breakwater to protect urban settlements", but experts highlighted the difficulties of building this type of structure on an Atlantic shoreline. Through the discussions, participants became aware of a variety of possible technical options and of the complexity of different costs, and levels of efficiency weighted on the decision-making process.

\section{Shared future vision}

There was a prevailing aspiration for securing the well-being of future generations, which was expressed by participants at several instances throughout the participatory experience. As one person stated, "I

Table 2. Coastal protection solutions, technical options and uncertainties.

\begin{tabular}{|c|c|}
\hline Coastal protection solutions & Technical options and uncertainties \\
\hline $\begin{array}{l}\text { Maintain existing coastal defence infra- } \\
\text { structures }\end{array}$ & $\begin{array}{l}\text { Should some groynes be removed? Doubts over a need for the reorientation of the } \\
\text { Barra-Aveiro Harbour southern groyne }\end{array}$ \\
\hline $\begin{array}{l}\text { Reinforcing the existing structures along } \\
\text { the southern part of the Ria de Aveiro } \\
\text { (two low sand dykes) }\end{array}$ & Expropriation of farming lands; use of sediments from Ria dredging operations \\
\hline $\begin{array}{l}\text { Maintain the beaches with sand nourish- } \\
\text { ment operations }\end{array}$ & $\begin{array}{l}\text { Technical options: sand sediment transport via road from harbour dredgings or from } \\
\text { forest areas; sediment transport via sea from beach north of Aveiro Harbour, or from } \\
\text { offshore dredging; quantity of sand and frequency of operations }\end{array}$ \\
\hline $\begin{array}{l}\text { Strengthening and protecting the dune } \\
\text { system }\end{array}$ & $\begin{array}{l}\text { Technical options to be studied and assessed: building a sand dyke with sediments from } \\
\text { Ria dredging; dunes reinforced using geotubes; sediments from harbour dredging }\end{array}$ \\
\hline Dredging inside the Ria de Aveiro lagoon & No technical options discussed \\
\hline Submerged detached breakwaters & $\begin{array}{l}\text { Either in front of Barra Beach or of Vagueira Beach, or both. The intervention needs to be } \\
\text { studied and tested in a pilot-experience }\end{array}$ \\
\hline Sea walls and groynes & $\begin{array}{l}\text { Sea walls as alternatives or as a complement to a submerged detached breakwater. Need } \\
\text { for further studies and pilot-experience }\end{array}$ \\
\hline Palisades and walkways & No technical options discussed \\
\hline
\end{tabular}




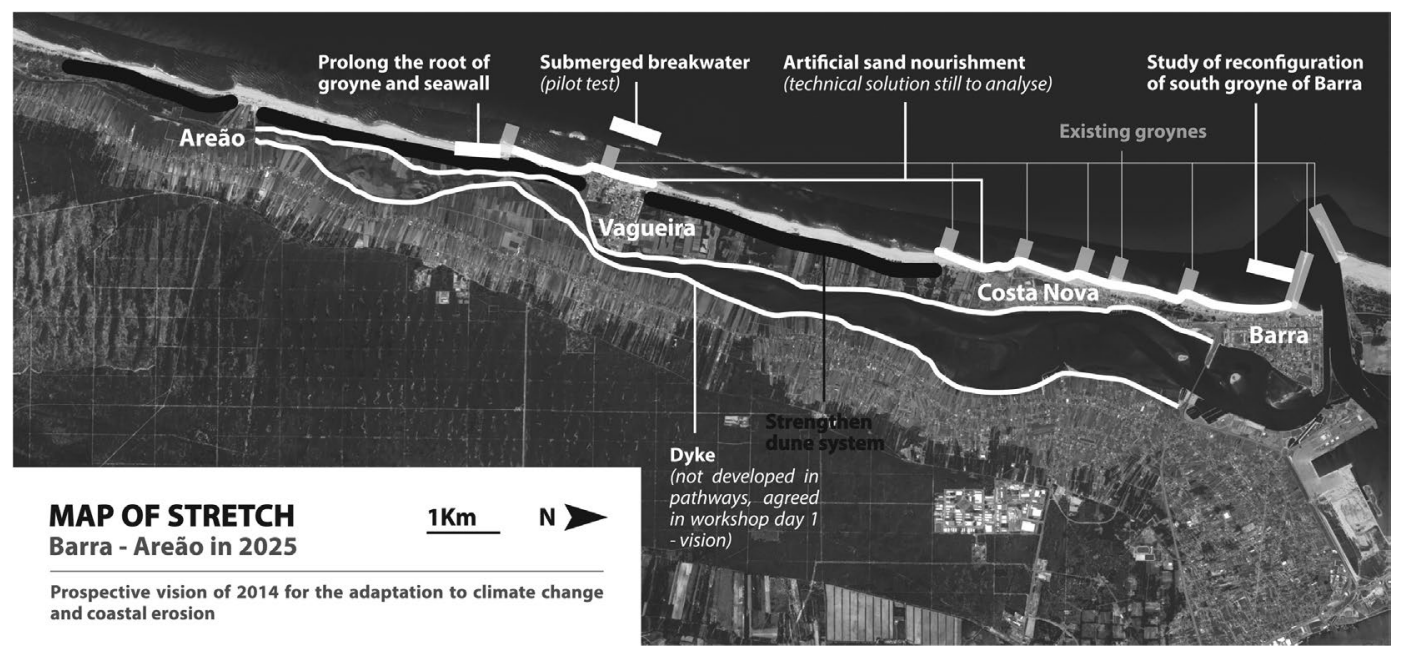

Figure 3. Map of consensus: prospective vision for adaptation to climate change and coastal erosion.

hope that what we do now helps to grant my children and grandchildren a pleasant and safe place to live." The different aspirations of individual participants regarding the future found resonance in the following shared goals.

(1) "Hold the coastline up to 2100, protect populated areas and existent infrastructures and constructions."

(2) "The formation of a new inlet [between the sea and the lagoon, due to a disruption of the sand spit and the dune system] cannot be allowed."

(3) "Relocation of populated settlements is not acceptable [by all], except for non-urban areas if necessary to advance with protection constructions."

(4) "Keeping the beaches as they are now is fundamental for economic activities, but also for preserving the local cultural identity and social life, strongly intertwined with the presence of the beach."

(5) "Harmonize coastal protection and the ecological preservation of the lagoon system to provide future generations with a sustainable and attractive coast to live on."

The map of consensus (see Figure 3) illustrates the decisions of the group and the choices made for protecting the coast (see Table 2 above).

\section{Adaptation pathways}

During the second workshop day discussions were geared towards tangible technical solutions necessary to achieve the goals identified, particularly the harmonization between holding the line and keeping the natural ecology of the region. The outcome of the discussions is shown by the adaptation pathways until 2100, where each chosen measure is represented according to tipping points. Figure 4 illustrates the final adaptation pathways.

To implement the adaptation measures suggested in these pathways, the group believed that there should be a joint financial plan; $70-80 \%$ would come from the European Union (EU) financial mechanisms; $20-30 \%$ from Portuguese governmental agencies and local authorities. Overall, responsibility 


\section{ADAPTATION PATHWAYS}

Stretch: Barra - Areão

Objectives: A) Protect populations and keep beach; B) Stop the breaking of the dune system and connection of the sea to the lagoon

2014 2040 2070 2100

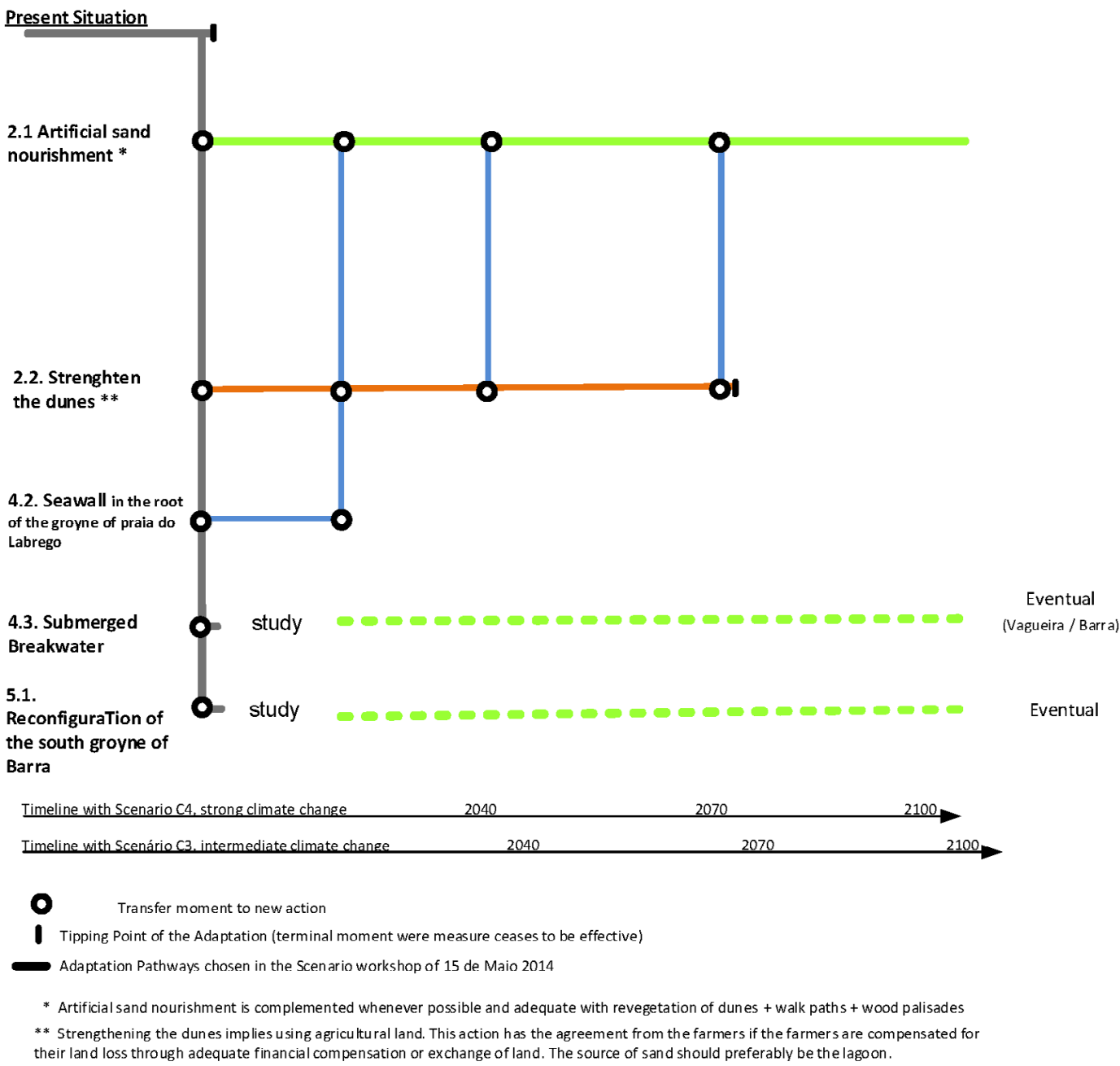

Figure 4. Final adaptation pathways for the coastal stretch of Ílhavo (Barra Beach) and Vagos (Areão Beach).

for financing adaptation was attributed to public investment, namely the EU, central government and local authorities. The agreed options for the future were as follows.

(1) "From the present and up to 2100 , sand nourishment operations." This solution would benefit the entire coastal system with the addition of sediments. Technical options were discussed regarding where to collect sand sediments, and the quantities of sand required until 2100. It was agreed that although additional studies were needed concerning technical options and their costs, sand nourishment operations should be part of the final pathway. 
(2) "Strengthening the dune system (with a sand dyke) to prevent a new inlet into the lagoon." This intervention was the most controversial for participants, because it implied the legal expropriation of farm lands and compensations to farmers. While some claimed protecting the dune system was a priority, others were suspicious of how the process would be endorsed so that farmers did not incur losses. The presence of both technicians and representatives of governmental agencies helped clarify the legal procedures of expropriation for protecting constructions. It was explained that all landowners would be compensated, either through land exchange or payments; which meant they would still be able to continue their farming activities. Following these explanations, representatives of local farmers and landowners admitted the solution could be viable and it was included in the final pathway.

(3) "A sea wall should be built at the root of an already existing groyne (Labrego Beach, south of the Vagueira settlement), and construction completed by 2025". Participants were well-aware of the particular vulnerability of that spot, affected by recurrent flooding due to erosion. After discussing a number of solutions, the final option was to strengthen the root of the existing groyne.

(4) "Two projects are suggested pending further studies (to be made until 2025): a submerged detached breakwater and the reconfiguration of the southern breakwater of the Barra inlet." The submerged detached breakwater could change local ecological, social and economic dynamics. The measure was supported by policymakers, local business owners and residents as an option that would provide the best and safest solution. Engineers and planners were not as committed to this option, given the uncertainties regarding how a submerged detached breakwater withstands the strong energetic wave climate of the Atlantic coast. The final decision was to include a study period for the intervention and gather more data regarding its effects. As for the reconfiguration of the southern breakwater of the Barra inlet, which belongs to the Aveiro Harbour Administration, the intervention was called for by local residents who claimed the Aveiro Harbour's southern groyne was preventing the natural flow of sediments to the beaches. Although this has been denied by the Aveiro Harbour Administration, it was agreed a study would be carried out by an independent body to assess the impact of the groyne in the dynamics of the natural ecosystem.

"(5) Monitoring of sea level and costal erosion."The potential adaptation options foreseen until 2100 are dependent on the evolution of observed sea level rises and coastal erosion. To anticipate these changes, periodic monitoring activities were included in the plan and were expected to be led by the University of Aveiro and the Aveiro Harbour Administration.

\section{Evaluation and next steps}

As manifested by those interviewed after the workshops (Table 3 provides a synthesis of these results), the participatory experience offered the opportunity to begin a discussion on the technical complexities of coastal interventions, highlighting the multiplicity of options and costs as well as potential secondary effects of different measures. A number of misassumptions about technical solutions were demystified, such as the idea that "putting sand on the drift [sediments from dredging operations] is throwing it away," as stated by an engineer. Some issues were for the first time discussed together, namely the discrepancies in price ranges between using sediments from offshore and harbour dredging, using sea versus land transportation; and regarding the quantities of sediments used, or the periodicity of the interventions.

Planners and experts felt that the experience did not reflect real-world planning activities: "that was paradise, out here it is a jungle and we hardly discuss issues together", believing that replicating the methodology in their institutions could make a difference. A farmer claimed he had valued "being 
Table 3. Interview themes and synthesis of responses.

\begin{tabular}{|c|c|}
\hline Themes & Synthesis of responses \\
\hline Promote long-term planning & $\begin{array}{l}\text { The need for a long-term planning is valorized; learned that potential adaptations refer to various } \\
\text { technical options; learned that a wide range of costs needs to be studied; demystified assump- } \\
\text { tions regarding engineering interventions }\end{array}$ \\
\hline $\begin{array}{l}\text { Participation (strengths and } \\
\text { weaknesses) }\end{array}$ & $\begin{array}{l}\text { Workshops provided a collaborative forum for discussion; promoted mutual understanding among } \\
\text { participants; conveyed the meeting of different knowledge systems and experiences; visual } \\
\text { materials delivered a clear understanding of possible future risks; social learning experience, } \\
\text { replicable in their own institutions. It is very different from "the real world" }\end{array}$ \\
\hline $\begin{array}{l}\text { Strategies to support implemen- } \\
\text { tation }\end{array}$ & $\begin{array}{l}\text { Technical studies for proposed engineering interventions (e.g. detached submerged breakwater) } \\
\text { Economic assessments of different technical options for measures (e.g. cost-benefit analysis) } \\
\text { engage media and society at large, dissemination and awareness raising }\end{array}$ \\
\hline
\end{tabular}

heard in a room full of policymakers". Policy actors and administrators thought the method facilitated mutual understanding; as one noted, "decisions should be ideally made together by all those with vested interests in the region". Residents and business owners emphasized that collaborative planning was pointless unless some measures were implemented. "If there is plenty of sand on the beach that is a start," said a resident. As pointed out by two planners, the workshop discussions failed to appropriately address policy and administrative legal instruments, such as land use plans, which should be part of a strategy for the region.

To push forward the implementation of measures, policymakers and planners highlighted the importance of economic assessments of costs and potential benefits and effectiveness of the interventions suggested. Engineers and planners were concerned with developing more technical studies of the engineering interventions. Residents, fishermen and farmers were more argumentative about the need for involving the media.

\section{After the SWAP}

Following the SWAP, an economic cost-benefit analysis of the chosen adaptation options was developed by the research group to meet the needs for further studies highlighted by participants. The results of the analysis were presented in June 2015 to participants and invited regional and national policymakers. The study's main conclusion was that combining small artificial sand beach nourishments and major hard intervention measures would be a better solution from the economic point of view. Informed by these results, the two municipalities continued developing projects to support the implementation of measures. Currently, one of the municipalities is developing a strategy to integrate the adaptation measures in municipal land use plans. Another municipality is developing a technical study on the detached submerged breakwater suggested in the final pathways (and recommended in the cost-benefit analysis). Lastly, some of the options represented by the adaptation pathways are now included as a strategic reference for the 2016 revised coastal zone management programme for the stretch of Ovar-Marinha Grande which encompasses the case study area. These new action research cycles involve a wider diversity and number of stakeholder groups (i.e. other municipalities in the region and the National Environmental Agency) across different levels and scales of governance.

\section{Discussion}

As has been hypothesized in the introduction, the case study shows that a participatory action research approach (Wittmayer \& Schäpke, 2014) which took stock of scenario methods and tools was able to accelerate a long-term adaptation process (Amaru \& Chhetri, 2013). Yet the results provide additional 
insights that explain the impact of the methodology in promoting an adaptation process, but also its limitations throughout the process.

First, the transdisciplinary action research approach was successful in accelerating climate change adaptation planning. As an alternative to a managerial and top-down approach (which is the more usual mode of planning in the region, see O'Riordan et al., 2014), the experience encouraged an adaptation process based on a participatory experience (i.e. SWAP). The use of the adaptation pathways and tipping-points tool in the context of the scenario workshop helped capacitate participants and ensure the problem was understood by individuals with diverse knowledge and information backgrounds. The adaptation pathways - a computational-based instrument for decision-making - benefited from being incorporated into a participatory context. The new application of the tool emphasized the importance of allowing people to define their future pathways. This indicates a successful transdisciplinary experience (Mansilla, Lamont, \& Sato, 2015) as people were able to share their knowledge and experiences in a collective learning process (Armitage et al., 2008). The SWAP also had an impact on spatial planners and policymakers involved, who manifested the intention to replicate the approach in their institutions. However, to maintain an inclusive process throughout the following action research cycles depends largely on the will of the policymakers involved. Despite the acceptance of participation as part of the planning process, current developments are largely steered by the two municipalities involved, who may not always be concerned with including all those with a stake in the decisions made.

Second, a shared future vision was achieved, despite the different stakeholder views and interests. This vision was shaped by two goals: preserving the ecological beauty of the landscape, and maintaining the current shoreline. Future storyline B described sequential adaptation actions for holding the shoreline at the cost of extremely high financial investments and a grey landscape of hard engineering constructions. Participants criticized this storyline and hoped to keep the natural ecosystem while protecting people and goods. Yet it is questionable whether keeping the current ways of living on the coast is possible, given the potential risks posed by climate change impacts in a system already extremely affected by coastal erosion. Conversely, hard engineering measures may result in a new technical landscape which radically alters local governance structures, cultures and practices (Kates et al., 2012). Participants appeared to understand that an undesirable systems collapse could be more difficult to prevent (Park et al., 2012) if the diverse types of measures were not thought through. Although the measures proposed were aiming towards an incremental adaptation process (i.e. maintaining the core functioning and structures of the shoreline), the end result could be transformational. That is, if hard engineering interventions predominate in the future, the socio-ecological system is likely to be radically altered (Park et al., 2012).The shared vision may have motivated local action, yet it has been far from realistic, as the two primary goals are essentially conflictual. Ultimately, a reflection on the limits to adaptation (Dow et al., 2013) was missing from the discussions and should be integrated in future planning stages.

Third, given the importance of local cultures, worldviews and perceptions (Adger et al., 2013), the framing and storylines articulated throughout the SWAP process appeared to be important triggers for allocating resources in the following research cycles. For instance, the narrative of protecting the coastal system (from perceived erosion and the potential aggravating effect of rising sea levels), while preserving, where possible, its natural beauty and touristic attractions (i.e. white sandy beaches and surfing spots), promoted additional studies. This framing also pushed the allocation of resources for the adaptation process through the ongoing efforts of the two municipalities towards implementing policies and measures. Given the built-in mechanisms in the final adaptation pathways for monitoring progress on adaptation policies and impacts, the approach was able to resolve the challenge of 
measuring progress on adaptation, which is important for securing future funding (Ford et al., 2013). However, this advantage is limited by the institutions responsible for monitoring, who are not legally bound to do so. Therefore, implementing the plan is highly dependent on the shared responsibility and commitment of those who were involved.

Fourth, the case study reinforces the argument that adaptation processes benefit from integrating different knowledge domains and systems of thinking (Folke et al., 2005; Olsson et al., 2006). It seems important to embed social learning processes within the research methodology (e.g. discussions to prepare stakeholders for the scenario workshop), and prepare stakeholders for the discussions by establishing a common knowledge background on the topics at stake. Yet, although the transdisciplinary context (Hadorn et al., 2006) was a benefit of the methodology, the workshops similarly highlighted the type of knowledge missing. For instance, issues of legislation and land use management were raised, but not followed through. Legislative knowledge was neither provided by researchers, nor by participants. Yet, legislation is of central importance for adaptation, as coastline infrastructures are regulated by coastal zone management programmes, and by international regulatory frameworks (e.g. the EU flooding directive, 2007/60/EC), which need to be accounted for.

Fifth, the study shows climate change adaptation appears to be strongly linked to political choices and is not only a matter of finding appropriate technical options and attractive economic solutions. Despite experts in the workshop favouring sand nourishment operations as the best option, the economic cost-benefit analysis highlighted that hard engineering interventions were the most attractive solutions from the economic perspective (although maybe not the best choice in order to preserve the natural ecosystem). Municipal actors also supported this type of intervention, which was perceived by local residents as providing the biggest protection. Not surprisingly, current efforts to implement some of the measures are centred on studying and assessing the possibility for the submerged breakwater. Conversely, a more politically controversial solution, expropriating lands and building a sand dyke in one of the most vulnerable spots, remains on standby.

Finally, the case study shows that action research and scenario methods were important in developing a holistic approach to climate change adaptation that accounted for the complexity of societal changes, and the different sociopolitical, technical and ecological dimensions. By linking action and research, the approach supported a planning process that accounted for the multiple challenges of climate change adaptation. A fuller theory of climate change adaptation needs to articulate scientific and technical knowledge with cultural and political dimensions (Wise et al., 2014). There should be a stronger emphasis on equity considerations, based on a collective governance framework that accounts for the losers and winners in both present and future generations (Adger et al., 2013; Pelling et al., 2014). Planning climate change adaptation has to go far beyond the technical dimension and truly emerge from the interrelation of societal responses and global and local systemic changes that take into account those affected (in the present and the future), by decisions made (Wise et al., 2014).

\section{Conclusion}

Action research accelerated climate change adaptation planning. It also shaped methodological tools and instruments to contextualise specific needs as well as the perceptions and world views of local actors. The study shows that participatory action research and qualitative scenario methods can ignite a climate change adaptation process. This can be achieved in a context where, despite perceived vulnerabilities, the active engagement in planning of interested stakeholders seems to be dependent on mediators, facilitators and connectors, which were roles taken up by the research team involved. 
Although the methodological approach was designed to respond to specific challenges (i.e. inclusiveness and collaboration issues), its application can be replicable in a diversity of contexts around the globe dealing with the challenges of climate change planning (e.g. uncertainty, complexity and the long time frame), and be flexible enough to account for situated cultural and political dynamics in the planning process.

The study also finds that if a transdisciplinary participatory action research process is a starting point, top-down strategies should provide enough support to communities for continual engagement, if necessary through directives for participation, not merely as a recommendation, but as a key component of an adaptation strategy or plan. A holistic approach to climate change adaptation planning will depend on the meeting of managerial and top-down approaches and initiatives driven through an inclusive and collective action research process.

Framing climate change as part of a broader sustainability challenge seems to contribute to supporting the development of a long-term plan, capable of accounting for the resilience and adaptability of both present and future generations. Further research (in the case study and elsewhere) will need to take stock of a holistic approach, across scales and levels of governance, capable of intertwining equity considerations, and the distribution of capacity building and vulnerability awareness, as well as political relationships. To contribute to a broader assessment of climate change adaptation processes, future research could experiment with more ethnographically based long-term processes of interviewing and recording (including video and audio diaries), as well as computer-based tools (e.g. allowing the use of smart phones to record real-time data of flood zones and warning systems for storm surges), and continuing to build on a portfolio of social learning processes.

Lastly, the experience highlights the importance of taking on an ontological perspective based on a "knowledge production in action". Action research approaches for climate change adaptation planning and the combination of scientific and real-life knowledge acted as drivers for change in planning practices, creating the possibility for transforming transdisciplinary knowledge into adaptable and consensual solutions. Beyond the role of action research in planning activities, the case study illustrates the need to maintain a critical appraisal of the direction in which adaptation processes are heading, including acknowledging the limitations to adaptation. Climate change adaptation planning can be part of a governance for transformation that encompasses integrated measures, considering social, ecological, economic and political dimensions, and instilling new practices and new modes of planning framed by inter-generational sustainability and resilience principles.

\section{Acknowledgements}

The authors thank all those who have participated in the research. The authors are grateful to Deltares Institute; and in particular to Marjolin Haasnoot and Ad Jeuken, who provided information on potential adaptation actions for this case study research, as well as fundamental guidelines for using the adaptation pathways and tipping-points method.

\section{Disclosure statement}

No potential conflict of interest was reported by the authors.

\section{Funding}

The research leading to this paper has been done in the context of the FP7 project Bottom-up Climate Adaptation Strategies for a Sustainable Europe (BASE, http://base-adaptation.eu/)], Directorate-General for Research and Innovation grant agreement no. 308337. The contents of the paper do not reflect the views or opinions of the 
European Commission. The Fundação para a Ciência e Tecnologia (FCT) was responsible for the financial support of Gil Penha-Lopes (scholarship SFRH/BPD/65977/2009) and of André Vizinho (FCT grant PD/PB/113929/2015). $\mathrm{Ce} 3 \mathrm{C}$ is a beneficiary of the Fundação para a Ciência e Tecnologia FCT Unit funding Ref. UID/BIA/00329/2013. The authors declare that they have no conflict of interest.

\section{Notes on contributors}

Inês Campos is a social scientist, with a PhD on climate change and sustainable development policies, in the field of sociology. Her research focused on addressing innovative approaches and developing frameworks built upon a convergence of methodologies from interdisciplinary and transdisciplinary research fields, with a particular attention to the role of action research, scenario methods and new governance designs for promoting collective action towards sustainable development. In recent years, her work has focused on designing, developing and applying methodologies for empirical research on bottom-up climate change adaptation case studies in Portugal, with a particular interest in societal transformation and climate change adaptation planning processes.

André Vizinho is a grant researcher working for the BASE and Adapt for Change projects. In both projects he is a coordinator of case studies. He works with participatory action research methodologies for the creation of resilient landscapes adapted to climate change.

Carlos Coelho's research is in the area of sediment transport, geomorphology and coastal protection - forecasts in the medium to long term, numerical modelling, vulnerability and risk classification of coastal areas and integrated coastal zone planning and management. Carlos Coelho also collaborates on consultancy work, developing coastal management plans and sediment dynamics studies.

Fátima Alves has a PhD in sciences applied to the environment from the University of Aveiro. She is a professor in the Department of Environment and Planning at the University of Aveiro and a researcher at the Centre for Environmental and Marine Studies (CESAM). With more than 22 years of professional experience, her main fields of expertise are integrated coastal and marine management, spatial planning of protected areas, strategic planning, risk assessment and management, coastal and marine governance.

Mónica Truninger is a sociologist and senior research fellow at the Institute of Social Sciences at the University of Lisbon. Her research interests are on food consumption and sustainability.

Carla Pereira's research is in the area of coastal protection, using numerical modelling, studying sediment transport, geomorphology, shoreline evolution, vulnerability and risk classification of coastal areas and integrated coastal zone planning and management. She collaborates on consultancy work, developing coastal management plans and sediment dynamics studies.

Filipe Duarte Santos holds a Master of Science in geophysics from the University of Lisbon and a PhD in theoretical physics from the University of London. He has been a professor of physics, geophysics and environment at the University of Lisbon since 1979, and Director of the PhD programme on climate change and sustainable development policies, which involves the University of Lisbon and the New University of Lisbon (http://alteracoesclimaticas.ics.ulisboa.pt/).

Gil Penha Lopes is an invited professor at the Faculty of Sciences, University of Lisbon, and lecturer on the topics of climate change and sustainable development. Currently he coordinates/participates in national and European research projects on local climate change adaptation and integral resilience.

\section{References}

Adger, W. N. (2006). Vulnerability. Global Environmental Change, 16, 268-281. doi:10.1016/j.gloenvcha.2006.02.006 Adger, W. N., Barnett, J., Brown, K., Marshall, N., \& O'Brien, K. (2013). Cultural dimensions of climate change impacts and adaptation. Nature Climate Change, 3, 112-117. doi:10.1038/NCLIMATE1666. 
Agarwal, A., Perrin, N., Chatre, A., Benson, C. S., \& Kononen, M. (2012). Climate policy processes, local institutions, and adaptation actions: Mechanisms of translation and influence. Wiley Interdisciplinary Reviews: Climate Change, 3, 565-579. doi:10.1002/wcc.193

Altrichter, H., Kemmis, S., McTaggart, R., \& Zuber-Skerritt, O. (2002). The concept of action research. The Learning Organization, 9, 125-131. doi:10.1108/09696470210428840

Alves, F. L., Silva, J. V., Pereira, C. A., \& Sousa, L. P. (2011). Ten years assessment of ICZM principles applied at local scale: Ria de Aveiro case study. Journal Of Coastal Research, 64, 1311-1315.

Alves, F. L., Sousa, L. P., Almodovar, M., \& Phillips, M. R. (2013). Integrated coastal zone management (ICZM): A review of progress in Portuguese implementation. Regional Environmental Change, 13, 1031-1042. doi:10.1007/ s10113-012-0398-y

Alves, F. L., Sousa, L. P., Esteves, T. C., Oliveira, E. R., Antunes, I. C., Fernandes, M. D., \& Pereira, M. (2014). Trend Change(s) in Coastal Management Plans:The integration of short and medium term perspectives in the spatial planning process. Journal Of Coastal Research. SI, 70, 437-442. doi:10.2112/SI70-074.1

Amaru, S., \& Chhetri, N. B. (2013). Climate adaptation: Institutional response to environmental constraints, and the need for increased flexibility, participation, and integration of approaches. Applied Geography, 39, 128-139. doi:10.1016/j.apgeog.2012.12.006

Andersen, I. E., \& Jaeger, B. (1999). Scenario workshops and consensus conferences: Towards more democratic decision-making. Science and Public Policy, 26, 331-340. Retrieved from: http://ncdd.org/rc/wp-content/ uploads/2010/06/Andersen-ScenarioWorkshopsConsensusConfs.pdf

Armitage, D., Marschke, M., \& Plummer, R. (2008). Adaptive co-management and the paradox of learning. Global Environmental Change, 18, 86-98.

Avgitidou, S. (2009). Participation, roles and processes in a collaborative action research project: A reflexive account of the facilitator. Educational Action Research, 17, 585-600. doi:10.1080/09650790903309441

Berrang-Ford, L., Ford, J. D., \& Paterson, J. (2011). Are we adapting to climate change? Global Environmental Change, 21, 25-33. doi:10.1016/j.gloenvcha.2010.09.012

Carvalho, A., Schmidt, L., Santos, F. D., \& Delicado, A. (2014). Climate change research and policy in Portugal. Wiley Interdisciplinary Reviews: Climate Change, 5, 199-217. doi:10.1002/wcc.258

Cash, D. W., Adger, W. N., Berkes, F., Garden, P., Lebel, L., Olsson, P., ... \& Young, O. (2006). Scale and cross-scale dynamics: Governance and information in a multilevel world. Ecology and society, 11. Retrieved from: http:// www.ecologyandsociety.org/vol11/iss2/art8/

Coelho, C., Silva, R., Veloso-Gomes, F., \& Taveira-Pinto, F. (2009). Potential effects of climate change on northwest Portuguese coastal zones. ICES Journal of Marine Science: Journal du Conseil, 66, 1497-1507. doi:10.1093/icesjms/ fsp132

Dannevig, H., Rauken, T., \& Hovelsrud, G. (2012). Implementing adaptation to climate change at the local level. Local Environment, 17, 597-611. doi:10.1080/13549839.2012.678317

Dias, J. M., \& Alves, F. L. (2013). Risco de Cheias e Estratégias de Adaptação para a Zona Costeira e Lagunar da Ria de Aveiro. [Flood risks and adaptation strategies for the coastal zone and the Ria de Aveiro lagoon]. Aveiro University: CESAM - Centro de Estudos do Ambiente e do Mar. Retrieved from: http://la.cesam.ua.pt/Documentos/Risco_ de_Cheia.pdf

Dow, K., Berkhout, F., Preston, B. L., Klein, R. J., Midgley, G., \& Shaw, M. R. (2013). Limits to adaptation. Nature Climate Change, 3, 305-307. doi:10.1038/nclimate1847

ESPON. (2013) Climate Change and Territorial Effects on Regions and Local Economies. Report. Retrieved from: http://citeseerx.ist.psu.edu/viewdoc/download?doi=10.1.1.449.9185\&rep=rep1\&type=pdf

European Commission. EU flooding directive, 2007/60/EC. Retrieved from http://ec.europa.eu/environment/water/ flood_risk/

Folke, C., Hahn, T., Olsson, P., \& Norberg, J. (2005). Adaptive governance of social-ecological systems. Annual Review of Environment and Resources, 30, 441-473. doi:10.1146/annurev.energy.30.050504.144511

Ford, J. D., Berrang-ford, L., Lesnikowski, A., Barrera, M., \& Heymann, S. J. (2013). How to track adaptation to climate change : A typology of approaches for national-level application. Ecology and Society, 18, 40. doi:10.5751/ES05732-180340

Ford, J. D., Berrang-Ford, L., \& Paterson, J. (2011). A systematic review of observed climate change adaptation in developed nations. Climatic Change, 106, 327-336. doi:10.1007/s10584-011-0045-5 
Fortunato, A. B., Rodrigues, M., Dias, J. M., Lopes, C., \& Oliveira, A. (2013). Generating inundation maps for a coastal lagoon: A case study in the Ria de Aveiro (Portugal). Ocean Engineering, 64, 60-71. doi:10.1016/j. oceaneng.2013.02.020

Haasnoot, M., Kwakkel, J. H., Walker, W. E., \& Maat, J. (2013). Dynamic adaptive policy pathways: A method for crafting robust decisions for a deeply uncertain world. Global Environmental Change, 23, 485-498. doi:10.1016/j. gloenvcha.2012.12.006

Hadorn, G., Bradley, D., \& Pohl, C. (2006). Implications of transdisciplinarity for sustainability research. Ecological Economics, 0. Retrieved from: http://www.sciencedirect.com/science/article/pii/S0921800905005781

Jäger J., Bohunovsky L., Binder J. (Eds.). 2008. Methods and tools for integrated sustainability assessment. Project Summary. Vienna, AUT: Sustainable Europe Research Institute. Retrieved from: http://www.slu.se/ pagefiles/58724/matisse.pdf

Juhola, S., \& Westerhoff, L. (2011). Challenges of adaptation to climate change across multiple scales: A case study of network governance in two European countries. Environmental science \& policy, 14, 239-247. doi:10.1016/j. envsci.2010.12.006

Kates, R. W., Travis, W. R., \& Wilbanks, T. J. (2012). Transformational adaptation when incremental adaptations to climate change are insufficient. Proceedings of the National Academy of Sciences, 109, 7156-7161. doi:10.1073/ pnas.1115521109

Kwadijk, J. C. J., Haasnoot, M., Mulder, J. P. M., Hoogvliet, M. M. C., Jeuken, A. B. M., van der Krogt, R. A. A., ... de Wit, M. J. M. (2010). Using adaptation tipping points to prepare for climate change and sea level rise: A case study in the Netherlands. WIREs Climate Change, 1, 729-740. doi:10.1002/wcc.64

Larsen, K., \& Gunnarsson-Östling, U. (2009). Climate change scenarios and citizen-participation: Mitigation and adaptation perspectives in constructing sustainable futures. Habitat International, 33, 260-266. doi:10.1016/j. habitatint.2008.10.007

Lopes, C. L., Silva, P. A., Dias, J. M., Rocha, A., Picado, A., Plecha, S., \& Fortunato, A. B. (2011). Local sea level change scenarios for the end of the 21 st century and potential physical impacts in the lower Ria de Aveiro (Portugal). Continental Shelf Research, 31, 1515-1526. doi:S0278434311002391

Mansilla, V. B., Lamont, M., \& Sato, K. (2015). Shared cognitive-emotional-interactional platforms markers and conditions for successful interdisciplinary collaborations. Science, Technology \& Human Values, 41, 571-612 0162243915614103.

McNiff, J. (2013). Action research: Principles and practice. London: Routledge.

Nisbet, M. C. (2009). Communicating climate change: Why frames matter for public engagement. Environment: Science and Policy for Sustainable Development, 51, 12-23. Retrieved from: http://www.climateaccess.org/sites/ default/files/Nisbet_Communicating\%20Climate\%20Change_0.pdf

O'Riordan, T., Gomes, C., \& Schmidt, L. (2014). The difficulties of designing future coastlines in the face of climate change. Landscape Research, 39, 613-630. doi:10.1080/01426397.2014.975108

Olsson, P., Gunderson, L. H., Carpenter, S. R., Ryan, P., Lebel, L., Folke, C., \& Holling, C. S. (2006). Shooting the rapids: Navigating transitions to adaptive governance of social-ecological systems. Ecology and society, 11 (18). Retrieved from: http://www.ecologyandsociety.org/vol11/iss1/art18/

Park, S. E., Marshall, N. A., Jakku, E., Dowd, A. M., Howden, S. M., Mendham, E., \& Fleming, A. (2012). Informing adaptation responses to climate change through theories of transformation. Global Environmental Change, 22, 115-126. doi:10.1016/j.gloenvcha.2011.10.003

Parry, M. L., Canziani, O. F., Palutikof, J. P., Van der Linden P. J., \& Hanson C. E. (Eds.). (2007). Contribution of Working Group II to the Fourth Assessment Report of the Intergovernmental Panel on Climate Change. Cambridge: Cambridge University Press. Retrieved from: http://www.ipcc.ch/publications_and_data/ar4/wg2/en/contents.html

Pelling, M., O'Brien, K., \& Matyas, D. (2014). Adaptation and transformation. Climatic Change, 133, 113-127, doi:10.1007/s10584-014-1303-0

Pereira, C., \& Coelho, C. (2013). Mapping erosion risk under different scenarios of climate change for Aveiro coast, Portugal. Natural Hazards, 69, 1033-1050. doi:10.1007/s11069-013-0748-1

PNAS. (2013). Relatório de Progresso Estratégia Nacional de Adaptação às Alterações Climáticas [Progress Report Portuguese National Adaptation Strategy for Climate Change]. Retrieved December 7, 2015, from http://www. apambiente.pt/_zdata/Politicas/AlteracoesClimaticas/Adaptacao/ENAAC/RelatProgresso/Relat_Progresso.pdf

Porter, J. J., Demeritt, D., \& Dessai, S. (2015). The right stuff? informing adaptation to climate change in British local government. Global Environmental Change, 35, 411-422. doi:10.1016/j.gloenvcha.2015.10.004 
Santos, F. D., \& Miranda, P. (Eds.). (2006). Climate change in Portugal. Scenarios, impacts and adaptation measures, SIAM II Project. Lisboa: Gradiva.

Schmidt, L., Gomes, C., Guerreiro, S., \& O'Riordan, T. (2014). Are we all on the same boat? The challenge of adaptation facing Portuguese coastal communities: Risk perception, trust-building and genuine participation, Land Use Policy, 38, 355-365. doi:10.1016/j.landusepol.2013.11.008

Schmidt-Thomé, P., \& Klein, J. (2013). Climate change adaptation in practice - from strategy development to implementation. Chichester, UK: Wiley-Blackwell.

Schmidt, L., Delicado, A., Gomes, C., Granjo P., Guerreiro, S., Horta, A., ... Penha-Lopes, G. (2013a). Change in the way we live and plan the coast: Stakeholders discussions on future scenarios and adaptation strategies. In D. C. Conley, G. Masselink, P. E. Russell, \& T. J. O'Hare (Eds.), Proceedings 12th International Coastal Symposium (Plymouth, England) Journal of Coastal Research, Special Issue No. 65, 1033-1038, ISSN 0749-0208. Retrived from: http://ics2013.org/papers/Paper4333_rev.pdf

Schmidt, L., Prista, P., Saraiva, T., O'Riordan, T., \& Gomes, C. (2013b). Adapting governance for coastal change in Portugal. Land Use Policy, 31, 314-325. doi:10.1016/j.landusepol.2012.07.012

Solomon, S., Qin D., Manning, M., Chen, Z., Marquis, M., Averyt, K. B., ... Miller, H. L. (Eds.). (2007). Contribution of working group I to the fourth assessment report of the intergovernmental panel on climate change. Cambridge: Cambridge University Press. Retrieved from: http://www.ipcc.ch/publications_and_data/ar4/wg2/en/contents. html

Sondeijker, S. A. G. C. (2009). Imagining sustainability: Methodological building blocks for transition scenarios. Erasmos University Rotterdam. Retrieved from http://hdl.handle.net/1765/17462

Tompkins, E. L., Adger, W. N., Boyd, E., Nicholson-Cole, S., Weatherhead, K., \& Arnell, N. (2010). Observed adaptation to climate change: UK evidence of transition to a well-adapting society. Global Environmental Change, 20, 627635. doi:10.1016/j.gloenvcha.2010.05.001

VISIO. (2010) [Computer Software] Microsoft. https://products.office.com/pt-pt/visio/flowchart-software

Walker, W. E., Haasnoot, M., \& Kwakkel, J. H. (2013). Adapt or perish: A review of planning approaches for adaptation under deep uncertainty. Sustainability, 5, 955-979. doi:10.3390/su5030955

Westley, F., Olsson, P., Folke, C., Homer-Dixon, T., Vredenburg, H., Loorbach, D., ... Thompson John (2011). Tipping towards sustainability: Emerging pathways of transformation. AMBIO, a journal of the human environment, 40, 762-780. doi:10.1007/s13280-011-0186-9

Wise, R. M., Fazey, I., Stafford Smith, M. S., Park, S. E., Eakin, H. C., Archer Van Garderen, E. A., \& Campbell, B. (2014). Reconceptualising adaptation to climate change as part of pathways of change and response. Global Environmental Change, 28, 325-336.

Wittmayer, J. M., \& Schäpke, N. (2014). Action, research and participation: Roles of researchers in sustainability transitions. Sustainability Science, 9, 483-496. doi:10.1007/s11625-014-0258-4

Wood, D., \& Stocker, L. (2009). Coastal adaptation to climate change: Towards reflexive governance. The International Journal of Science in Society, 1, 137-145. 